TERMINUS

t. 20 (2018), z. 2 (47), s. $255-281$

doi: $10.4467 / 20843844$ TE. 18.008 .9753

www.ejournals.eu/Terminus

Bartosz B. Awianowicz

http://orcid.org/0000-0001-7380-2272

Uniwersytet Mikołaja Kopernika w Toruniu

bartosz.awianowicz@umk.pl

\title{
Orator - rhetor - rhetorista w ujęciu Johanna Mochingera. Edycja i przekład trzech rozdziałów poświęconych mówcy, teoretykowi i adeptowi/krytykowi sztuki wymowy w Orator atque rhetorista ${ }^{1}$
}

Abstract

Orator-rhetor-rhetorista According to Johann Mochinger. An Edition and Translation of Three Chapters Dedicated to a Public Speaker, Theorist and Student/Critic of the Art of Eloquence in Orator atque rhetorista

Johann Mochinger (1603-1652), professor of rhetoric at the Academic Gymnasium in Gdańsk (1630 - 1652), was one of the most interesting teachers and theorists of rhetoric in the Polish-Lithuanian Commonwealth in the first half of the seventeenth century. While during the Thirty Years' War the Protestant teaching of rhetoric was often involved in religious disputations and controversies, Mochinger, though he was at the same time a preacher at the Lutheran Church of St. Catherine, plainly quoted many Jesuit treatises appreciating them as valuable sources

1 Tekst powstał dzięki kwerendom przeprowadzonym w ramach projektu Narodowego Centrum Nauki Miniatura 1 (2017/01/X/HS2/00695). 
of rhetoric theory both in his printed treatise, Floridorum e dissertationibus rhetoricis super Cicerone sylva (Gdańsk 1640) and Orator atque rhetorista (Gdańsk 1641), and in his manuscript lectures.

The aim of the paper is to present three chapters of Orator atque rhetorista by the Mochinger, the most important of his rhetoric works, in the Latin original and my Polish translation. All these chapters, dedicated to the terms related to orator (public speaker), rhetor (theorist/teacher of rhetoric) and rhetorista (advanced student and critic of the art of eloquence), well exemplify Mochinger's sources: Cicero's $D e$ oratore, Noctes Atticae by Aulus Gellius, Dialogus de oratoribus by Tacitus, Plutarch's De garrulitate and Vitae decem oratorum attributed to him, as well as commentaries by Petrus Mosellanus, the oration Ad studiosos eloquentiae in Academia Wittebergensi by the Lutheran Adam Theodor Siber, and Theatrum veterum rhetorum by the Jesuit Louis de Cressolles, De eloquentia sacra et humana by another Jesuit, Nicolas Caussin, and Prolusiones academicae by Famiano Strada. However, the new meaning of the word rhetorista and the broad application of it in his work are Mochinger's original invention. Not only did he devote a significant part of his treatise to define the term and to describe the duties of a rhetorista, but he also willingly used it in his later works, e.g. in Eloquentiae cupidissimos rhetoristas ad acroases oratorias frequenter iterum obeundas, quae (quod optimum maximum Numen iubeat!) auspicato rursus inchoabuntur, posteaquam quidem, solito in Acroaterio Minori Lycei nostri, die Martii I. hora sueta IXa, de librorum Tullianorum quam maxime utiliter evolvendorum ratione multo commodissima, quasi in antecessum ... vocoque invitoque... (Gdańsk 1646).

Keywords: Johann Mochinger, early modern rhetoric, Latin rhetorical terms, rhetorical manuals

Gdy w roku 1630 katedrę retoryki Gdańskiego Gimnazjum Akademickiego powierzono dwudziestosiedmioletniemu Johannowi Mochingerowi (1603-1652), można się było spodziewać, że młody profesor będzie kształcił swych uczniów na biegłych polemistów luterańskich, którzy swą argumentację będą czerpać nie tylko z podręczników retoryki, lecz także z pism teologicznych, Biblii oraz historii konfliktów religijnych. Mochinger bowiem, jako wychowanek gimnazjów w rodzinnym Gdańsku oraz w Toruniu, następnie kształcący się na uniwersytetach w Wittenberdze, Lejdzie i Strasburgu (1620-1628), zadebiutował mową o słynnej rzezi hugenotów w noc św. Bartłomieja 
1572 roku: Oratio de nuptiis Gallicis famosis (1622), wkrótce po niej wydał dysputę uniwersytecką De amplificatione rerum publicarum (1623) i niewielki traktat z pogranicza filologii i teologii Discursus philologicus de nominibus Dei Hebraicis, biblicis et rabbinicis (1623) ${ }^{2}$, związek zaś Mochingera z Kościołem luterańskim przypieczętowało objęcie po powrocie do Gdańska w 1628 roku stanowiska diakona w kościele św. Katarzyny (od 1645 r. był pastorem tego kościoła).

Podczas swej dwudziestodwuletniej aktywności jako profesor retoryki (do śmierci w 1652 r.) Mochinger dał się jednak poznać nie tylko jako sprawny kaznodzieja i autor panegiryków (szczególnie na cześć królów Zygmunta III, Władysława IV i Jana Kazimierza), lecz przede wszystkim jako dość oryginalny i wszechstronny teoretyk wymowy, rozwijający definicje i klasyfikacje autorów zarówno protestanckich, jak i katolickich, w tym jezuitów. Otwartość gdańszczanina cechuje jego drukowane Floridorum e dissertationibus rhetoricis super Cicerone sylva (Gdańsk 1640), wiele rękopiśmiennych wykładów (w tym spisanych przez jego uczniów: Johannesa Tibiusa, Olausa Möllera i Melchiora Maiora), opartych zarówno na progymnasmatach Aftoniosa (greckiego retora $\mathrm{z}$ drugiej połowy IV $\mathrm{w}$. n.e.), jak i na opublikowanych już w XVII wieku pracach Gerarda Vossiusa (1577-1649) i jezuity Louisa de Cressolles (1568-1634), otwartość ta szczególnie zaś jest widoczna w wydanym w gdańskiej oficynie Andreasa Hünefelda traktacie Mochingera Orator atque rhetorista $(1641)^{3}$.

2 Na temat dwóch pierwszych szerzej pisał Bronisław Nadolski, Jan Mochinger - profesor retoryki w Gdańskim Gimnazjum Akademickim, „Rocznik Gdański” 22 (1963), s. 194-196.

3 Szerzej na temat życia i twórczości Mochingera zob. B.B. Awianowicz, $R e-$ toryka w Gdańskim Gimnazjum Akademickim w świetle programów szkolnych, wykładów i praktyki oratorskiej drugiej połowy XVI i XVII wieku, w: W gdańskim ogrodzie Muz. Gimnazjum Akademickie w Gdańsku wobec kultury starożytnych Greków i Rzymian, red. M. Otto, J. Pokrzywnicki, Pelplin 2015, s. 71-77 i 80-81 (bibliografia dzieł gdańskiego retora), oraz B. Nadolski, Jan Mochinger..., passim; idem, Ze studiów nad życiem literackim i kultura umysłowa na Pomorzu w XVI i XVII wieku, 
Już w samym tytule dzieła zwraca uwagę nowożytny neologizm rhetorista, który bodaj po raz pierwszy pojawił się w mało znanym wczesnym komentarzu Juana Luisa Vivesa (1492-1540) do IV księgi Rhetorica ad Herennium ${ }^{4}$ z 1518 roku, jednak w zupełnie innym, negatywnym kontekście. Hiszpański humanista krytykował bowiem współczesnych sobie niedouczonych nauczycieli (lub „literatów”5), którzy chcąc uchodzić za mówców, gonią jedynie za retorycznymi ozdobnikami, przez co „zwykł ich nazywać retorystami małpującymi mówców” („quos ego rhetoristas et oratorum simios solitus sum appellare” ${ }^{6}$. Gdański profesor nadaje zaś swemu „retoryście” inne, neutralne czy wręcz pozytywne znaczenie, będące dopełnieniem tradycyjnych antycznych terminów orator w znaczeniu „mówca” i rhetor w znaczeniu "nauczyciel wymowy”" Dla Mochingera rhetorista to wciąż adept retoryki, jednak adept już doświadczony, słuchacz

Wrocław 1969, s. 146-166. Por. też L. Mokrzecki, Jan Mochinger, w: Słownik biograficzny Pomorza Nadwiślańskiego, t. 3, red. Z. Nowak, Gdańsk 1997, s. 240. Na temat progymnasmatów Mochingera zob. też B.B. Awianowicz, Progymnasmata w teorii i praktyce szkoły humanistycznej od końca XV wieku do połowy XVIII wieku. Dzieje nowożytnej recepcji Aftoniosa od Rudolfa Agricoli do Johanna Christopha Gottscheda, Toruń 2008, s. 273-275.

4 Zob. J.L. Vives, Praelectio in quartum Rhetoricorum ad Herennium, w: idem, Early Writings 2. Epistula Forti, Vita Ioannis Dullardi, Christi Triumphus, Ovatio Mariae, Clipeus Christi, Praelectio in quartum Rhetoricorum ad Herennium, Praelectio in Convivia Philelphi, intr., critical ed., transl. and notes by J. IJsewijn, A. Fritsen, Ch. Fantazzi, Leiden 1991, s. 132. Zob. też J. Ramminger, Neulateinische Wortliste, hasło rhetorista, www.neulatein.de/words/1/006541.htm (dostęp: 16.05.2018).

5 Vives posługuje się tu terminem litteratores, nacechowanym pejoratywnie zapewne na podstawie lektury Noctes Atticae Gelliusza, w których $(18,9)$ czytamy m.in. „wśród obecnych jeden był literatorem, drugi znawcą literatury, to znaczy pierwszy nauczał, drugi był uczony” („ex his, qui aderant, alter litterator fuit, alter litteras sciens, id est alter docens, doctus alter"). Wszystkie przekłady z łaciny są mojego autorstwa.

6 J.L. Vives, Praelectio..., s. 132.

7 Na temat tego rozróżnienia zob. zwł. Cic., De orat. I 52 i 84-87, gdzie Arpinata wymiennie $\mathrm{z}$ rhetores stosuje określenie rhetorici illi doctores („owi nauczyciele retoryki”). Przekłady z De oratore za: $\mathrm{M}$. Tulliusz Cyceron, $O$ mówcy, przeł., wstęp i komentarz B. Awianowicz, Kęty 2010. 
ostatnich klas humanistycznych gimnazjów lub kolegiów. Co więcej, określeniu temu nie tylko nadał nowe znaczenie, lecz także sam chętnie posługiwał się nim w kontaktach ze swymi uczniami, czego dowodzi chociażby zaproszenie na publiczne wykłady (acroases oratoriae) 1 marca 1646 roku o pismach (sc. retorycznych) Cycerona, które kierował do „eloquentiae cupidissimos rhetoristas”.

Żeby dokładnie prześledzić wzajemne relacje terminologicznej triady orator - rhetor - rhetorista, a także poznać źródło wyeksponowanego w tytule Orator atque rhetorista nowego terminu, należy przyjrzeć się dokładniej przede wszystkim „wywodom” (dissertationes) I, II oraz XLIV Mochingerowego traktatu? . Wybór owych dissertationes pozwala zarówno prześledzić terminologię związaną z postaciami mówcy, nauczyciela i ucznia (jednak ucznia bardzo konkretnego - dojrzałego, będącego słuchaczem świadomym i krytycznym) sztuki wymowy, jak i zapoznać się ze swoistym lamentum siedemnastowiecznego nauczyciela eloquentiae nad upadkiem zainteresowania studiami retorycznymi. Nadto zamieszczone niżej rozdziały znakomicie ukazują lektury gdańskiego profesora, prezentując całe spektrum wykorzystanych przezeń źródeł, od antycznych: De oratore Cycerona, Dialogus de oratoribus Tacyta, De garrulitate Plutarcha i przypisywane mu Vitae decem oratorum oraz Noctes Atticae Aulusa Gelliusza, przez luterańskie: mowa Ad studiosos eloquentiae in Academia Wittebergensi Adama Theodora Sibera (1563-1616),

8 Zob. pełny tytuł: Eloquentiae cupidissimos rhetoristas ad acroases oratorias frequenter iterum obeundas, quae (quod optimum maximum Numen iubeat!) auspicato rursus inchoabuntur, posteaquam quidem, solito in Acroaterio Minori Lycei nostri, die Martii I. hora sueta IXa, de librorum Tullianorum quam maxime utiliter evolvendorum ratione multo commodissima, quasi in antecessum, audita fuerint quaedam, allocutione publica vocoque invitoque, Johannes Mochingerus, Gymnasii rhetor, anno Domini MDC XLVI, Gdańsk: Rhetius [1646] (egz. Biblioteki PAN w Gdańsku, sygn. Ma $\left.39842^{\circ}(82)\right)$. Po tytule następuje dedykacja zaczynająca się od słów: „Rhetoristis meis".

9 Zob. J. Mochinger, Orator atque rhetorista penicillo Iohannis Mochingeri depicti prodiere, Gdańsk: Andreas Hünefeld, 1641, s. 3-7 i 276-283. 
po dzieła jezuitów: Theatrum veterum rhetorum wspomnianego już Louisa de Cressolles, De eloquentia sacra et humana Nicolasa Caussina (1583-1651) i Prolusiones academicae Famiana Strady (15721649).

\section{Zasady wydania tekstu łacińskiego}

W stosunku do starego druku wprowadzono następujące zmiany:

- uwspółcześniono pisownię wielką literą, pozostawiając ją jedynie $\mathrm{w}$ zapisie imion własnych, podczas gdy w wydaniu Hünefelda wyróżniono za jej pomocą również kluczowe dla wywodu terminy: Orator, Oratio, Rhetor, Rhetorista, Rhetorica, ale też: Eloquens, przymiotnik Rhetoricus oraz Reges i Principes;

- ujednolicono pisownię półsamogłoski $i / j$, rezygnując ze spółgłoskowego zapisu $j$;

- ujednolicono pisownię $s$, rezygnując z zapisu długiego $s(()$;

- rozwiązania skrótów umieszczono w nawiasach okrągłych, na przykład lib(ro);

- ligaturowy zapis $\propto$, który w starym druku zastosowano do dyftongu $a e$, ale też oe, rozwinięto zgodnie z obecnie przyjmowaną ortografią, czyli na przykład proelio, nie praelio;

- ligaturowy zapis spójnika \& zastąpiono zapisem pełnym (et), a suspensję enklityki -q; rozwinięto do postaci -que;

- wprowadzono również nieznaczne zmiany $\mathrm{w}$ interpunkcji tekstu łacińskiego. 


\section{[Dissertatio] prima}

\section{De oratoris definitione}

Ac definitionem quidem, in qua veluti in angusta quadam tabella suis lineis depictus exhibeatur orator, principio afferentes, ordine, sicuti existimamus, auspicabimur. Eam sistimus duplicem: Ciceronianam unam, nostram alteram. Tullii autem sententia, quam ipsemet lib(ro) I De oratore sect(ione) 64 prodidit: Is est orator hoc tam gravi dignus nomine, qui quaecunque res inciderit, quae sit dictione explicanda, prudenter et copiose et ornate et memoriter dicat, cum quadam etiam actionis dignitate ${ }^{10}$. Sic ille ibidem loci eloquentem plenius descirptum ivit ${ }^{11}$, quanquam alibi, idem faciens, paulo utatur verbis sermonisque contextu brevioris. Post quem nos eum esse oratorem dicimus, qui vel omnibus, vel plerisque ac maxime necessariis ad bene dicendum praesidiis cum a natura propitia impetratis, tum cura acquisitis est instructus, adhaec vero faciendarum poliendarumque nec non habendarum orationum cumprimis est gnarus; dicens autem etiam admirabilis iudicio intelligentium videtur. Vel compendiosius: orator est bene dicendi peritus et ad eloquentiam vel aptus natus, vel studio et industria apprime fictus. Quibus in medium prolatis sive illam rhetorum oratorumque coryphaei ${ }^{12}$, sive

10 Na początku cytatu z Cycerona, w którym zdanie to wypowiada Lucjusz Licyniusz Krassus odgrywający w dialogu rolę alter ego samego autora, Mochinger zmienia czas i (nieznacznie) szyk - Cic. De orat. I 64: „is orator erit mea sententia $[\ldots]$ ".

11 Zob. Cic. De orat. I 65-73, Arpinata wyjaśnia tu, że pod stwierdzeniem „na każdy temat" kryje się wymóg dobrego wykształcenia ogólnego mówcy (w artes liberales, szczególnie zaś w filozofii moralnej), dodaje przy tym, że udane wystąpienie oratora wymaga też wcześniejszych ćwiczeń w szkolnych deklamacjach (I 73).

$12 \mathrm{Tj}$. Cycerona. O autentycznej fascynacji Mochingera Arpinatą świadczy dobitnie wcześniejszy traktat gdańszczanina, na który składają się notatki $\mathrm{z}$ jego wieloletnich zajęć w Gimnazjum Akademickim: Floridorum e disserationibus rhetoricis Johannis Mochingeri super Cicerone in Lyceo Gedanensi habitis excerptorum sylva, de qua, in certos quasi saltus distributa, lectissimi aliquot eloquentiae alumni, 
nostram descriptionem suo aliquis approbare velit calculo, sive alias, a se adornatas, afferre malit et istis iam praeferre, per nos faciat, non impediemus, dummodo a repraesentando ad summam oratore penicillo suo non nimiopere aberraverit. Haudquaquam tamen absque animi commotione audiremus, si quisquam cum Mnesarcho ${ }^{13}$, cuius Cicero lib(ro) I De oratore sect(ione) 83 meminit sive dicere, sive statuere apud se auderet: oratorem aliud esse nihil, quam operarium lingua celeri et exercitata ${ }^{14}$. Apage enim intolerabiles ineptias! Rectius sapiendum est iudicandumque.

\section{Rozprawa pierwsza}

\section{O definicji mówcy}

Zaczniemy zatem od definicji, w której, pilnując pierwotnego porządku, mówca zostanie przedstawiony tak, jak nam się wydaje, jakby sportretował się na jakimś niewielkim obrazku własną kreską. Definicję tę przywołujemy w dwóch postaciach: pierwszej autorstwa Cycerona, drugiej naszej własnej. Oto zdanie Tuliusza, które przedstawił w 64. akapicie I księgi O mówcy: „Ten jest mówcą godnym tego

facta sententiarum communicatione, nuncupandis suo loco diebus, sermones conferent, Gdańsk: Georg Rhete, 1640. Właściwy tekst traktatu poprzadza (ibidem, k. Br.) list Mochingera do jego uczniów („ad eloquentiae studiosissimos auditores”), rozpoczynający się zdaniem: „Przypadło mi dla waszej korzyści objaśniać Marka Tuliusza Cycerona, mieć na jego temat lekcje: [czynię] to, tak twierdzę, nie bez przyczyny, z pełną świadomością” („M.T. Ciceronem praelegere, scholasque super eo habere, vestri causa emolumenti, decretum mihi est: idque, ut autumo, nec temere, nec inconsulto"); kończy go zaś m.in. wyznanie (k. $\left[\mathrm{B}_{3}\right] \mathrm{r}$.), że Rzymianin „wydaje się doprawdy najgodniejszy, by każdy go kochał i naśladował” („revera amore ac imitatione quorumcunque videatur esse dignissimus").

13 Mnesarchos był uczniem słynnego stoika Panajtiosa (ok. 185-109 p.n.e.), a po jego śmierci został kierownikiem szkoły stoickiej w Atenach.

14 W oryginale Cycerona cytat w l. mn. - Cic. De orat. I 83: „Mnesarchus hos quos nos oratores vocaremus nihil esse dicebat nisi quosdam operarios lingua celeri et exercitata". 
jakże poważnego tytułu, kto na każdy temat, jaki przyjdzie mu przedstawić w mowie, będzie mówił mądrze i składnie oraz kunsztownie i z pamięci, jak również z pełną godności mimiką i gestykulacją" ${ }^{15}$. Tak on w tymże miejscu dokładniej jeszcze kontynuuje opis człowieka wymownego, chociaż gdzie indziej posługuje się nieco innymi słowami w kontekście krótszej wypowiedzi ${ }^{16}$. Po nim my sami twierdzimy, że mówcą jest ten, kto wyposażony jest zarówno w dane przez łaskawą naturę, jak i zdobyte dzięki pracy albo we wszystkie środki dobrego przemawiania, albo w ich większość, albo w te najbardziej potrzebne; wie przy tym przede wszystkim, jak przygotowywać, wygładzać i wygłaszać mowy; mówiąc zaś, wydaje się godny podziwu w oczach znawców. Albo zwięźlej: mówcą jest ktoś biegły w dobrym mówieniu i albo mający wrodzone predyspozycje do wymowy, albo nadzwyczaj dobrze do niej przygotowany dzięki gorliwości i pracy. Kiedy zatem przedłożyliśmy te definicje, może sobie ktoś zechce wybrać albo tę koryfeusza retorów i mówców, albo nasz własny opis, albo też będzie wolał wprowadzić inne, opracowane przez siebie, i już [nad tamte] przedłożyć; niech robi, jak chce, nie będziemy mu przeszkadzać, o ile tylko jego pędzel w najmniejszym stopniu nie odejdzie od przedstawiania mówcy w całości. Żadną miarą jednak nie będziemy ze spokojem wysłuchiwać, jeśli ktoś poważy się albo powtarzać za Mnesarchosem, którego Cyceron wspomina w akapicie 83. I księgi $O$ mówcy, albo samemu twierdzić, że „mówca nie jest niczym innym, jak tylko rzemieślnikiem obdarzonym szybkim

15 Przekład z De oratore (z niewielkimi zmianami) za: M. Tulliusz Cyceron, O mówcy..., s. 85. Definicja Krassusa/Cycerona obejmuje wszystkie pięć officia oratoris: do inwencji (inventio) retorycznej odnosi się „mądrze” (prudenter), do dyspozycji (dispositio) - „składnie” (composite), do elokucji (elocutio) - „kunsztownie” (ornate), do umiejętności pamięciowego opanowania mowy (memoria) - „z pamięci” (memoriter), a do actio (pronuntiatio) - „pełną godności mimiką i gestykulacją”.

16 Obecnego w oryginale terminu sermo Cyceron używa w całym De oratore albo w znaczeniu „rozmowa”, albo w połączeniu z przymiotnikiem Latinus jako ,język (łaciński)". 
i wyćwiczonym językiem”. Ale precz z nieznośnymi bzdurami! Lepiej zachować rozwagę i osądzać.

\section{[Dissertatio] secunda}

\section{De discrimine inter rhetorem et oratorem}

Huius loci esse iudicamus, quid rhetorem inter et oratorem intersit differentiae, paucissimis iuxta ac planissimis verbis aperire et exponere. Nempe rhetor recte audit, qui vel dicendi docet artificium et exercitationum viam commonstrat, vel rogatus etiam orationum dictionisque elaborationis ${ }^{17}$ formulas aliis praescribit, cum orator ille censeatur, qui, si valet eloquio, perorandi subit periculum et re ita exigente varia facultatis suae edit specimina, quae quo sunt perfectiora atque politiora, eo maius inde nomen claritudinemque adipiscitur. Sic etiam, ut id, quod dicimus, aliquo illustratum eamus exemplo: rhetor fuit Isocrates ${ }^{18}$, orator Demosthenes, Cicero iure utroque decorabitur nomine. Quod ipsum praeterea atque longe luculentius quoque non adeo paucorum autorum locis, iisque valde graphicis, in quibus nomina isthaec secundum dicti discriminis tenorem prolata fuere, declaratum dare admodum in proclivi esset ${ }^{19}$. Sed nos

17 W starym druku błędnie: elaboratioris.

18 Jedynie jako retor-nauczyciel wymowy występuje Isokrates (436-338 p.n.e.) dwukrotnie w obszernie wykorzystywanym tu przez Mochingera De oratore; zob. Cic. De orat. II 10 (,ille pater eloquentiae [...] Iscorates”), II 94 („Isocrates, magister istorum omnium"). Jednakże Cyceron chwali go w tym samym dziele również jako mówcę, którego styl odznaczał się słodyczą (suavitas), w jednym rzędzie z Lizjaszem, Hyperejdesem, Ajschynesem i Demostenesm (Cic. De orat. III 28).

19 Zapewne chodzi tu o tabelaryczne zestawienie autorów otwierające traktat De eloquentia sacra et humana Nicolasa Caussina, w którym wyszczególnieni są najpierw retorzy i autorzy traktatów retorycznych (rhetores et rhetoricorum scriptores) greccy i łacińscy, następnie również podzieleni na języki sofiści i filolodzy (sophistae et philologi), mówcy (oratores), filozofowie (philosophi - wyjątkowo bez podziału na Greków i Rzymian), historycy (historici) oraz ojcowie Kościoła (patres et scriptores sancti) - zob. N. Caussin, De eloquentia sacra et humana libri XVI. Editio tertia, non 
eadem conceptis verbis hic adducere minime institutum habemus, quae tamen, cum se in lectione offerent, a rhetoristis ${ }^{20}$ ad memoriam ut annotentur, non tantum non vetamus, verum hortatores quoque existimus.

Qua in re occupatos neutiquam tamen moveri velim, si nomenclaturae iam perstrictae ${ }^{21}$ nullam fuisse rationem habitam fortassitan rep $<\mathrm{p}>$ ererint, siquidem in vocibus varie usurpandis scriptores sibi multum sumere non possunt esse nescii. Sed vero fatemur, etiam ipsos quoque oratores ac primo omnium rhetorum esse insignitos nomine, quo de a Caussino lib(ro) I De eloquentia sacra et humana cap(ite) 6. tribus monemur ${ }^{22}$, a Cresollio vero in Theatro rhetorum uberius insuper edocemur ${ }^{23}$.

ignobili accessione locupleta, cum accuratis indicibus, tam eorum quae unoquoque capite continentur, quam rerum et verborum, Köln: Bernard Gualter, 1634, Operis sinopsis [jedna karta przed Index capitum et titulorum] - egz. ze zbiorów Biblioteki PAN w Gdańsku, sygn. Fa $382548^{\circ}$ (zarówno wcześniejsza sygn. XVII. A q. 2, jak i pergaminowa oprawa sugerują, że jest to egzemplarz, z którego korzystał sam Mochinger).

${ }_{20} \mathrm{~W}$ tym miejscu kontekst wyraźnie wskazuje na to, że termin rhetorista odnosi się do uczniów/słuchaczy wykładów retora.

${ }_{21}$ Najprawdopodobniej aluzja do: N. Caussin, De eloquentia sacra et humana libri XVI..., s. 6, gdzie czytamy, że „retorzy niegdyś przedkładali i tworzyli prawa, nazwa retoryki została jednak, jak się wydaje, zawężona do mów sądowych" („[...] rhetores olim leges proponerent et conderent; verum quod contracta videretur ad forenses orationes rhetoricae nomenclatura").

22 Francuski jezuita Caussin analizuje termin rhetor na podstawie źródeł greckich (począwszy od Homera, skończywszy na bizantyńskiej Księdze Suda), toteż nie akcentuje tak jak Mochinger właściwego dla łaciny rozróżnienia na orator - mówca i rhetor - teoretyk, nauczyciel wymowy. Owe trzy znaczenia terminu rhetor w powtarzającym ujęcie Księgi Suda dziele Caussina to: prawodawca, przywódca ludu (dux populi) i wreszcie nauczyciel wymowy i sofista (doctor eloquentiae et sophista); zob. N. Caussin, De eloquentia sacra et humana libri XVI..., s. 6-7.

${ }_{23}$ Cresollius poświęca szczególnie wiele uwagi rozróżnieniom terminów sophista i rhetor w źródłach greckich: antycznych (Platon, Plutarch, Filostratos), głównie jednak u późnoantycznych ojców Kościoła (Bazyli Wielki, Grzegorz z Nazjanzu, Jan Chryzostom, Klemens Aleksandryjski) i w bizantyńskiej księdze Suda oraz w łacińskich, przeważnie antycznych i późnoantycznych (obok Cycerona i Kwintyliana 
Nos autem, quod disertissime praedicimus, haud rhetorem, hoc est magistrum rhetoricum hic loci sumus delineaturi, sed oratorem duntaxat informaturi formaturique, genuina rhetoris eopse pacto defungentes opera nixu suo studioque oratorem parturientis. Et quandoquidem uno gemellos partu edere minime genitum ${ }^{24}$ monstrosum est, sed liberale, praeter oratorem et rhetoristam, hoc est discipulum rhetoricum, eodem conatu laboreque effictum effigiatumque in lucem dabimus. Haec semel dicta sunto, haudquaquam iteranda.

\section{Rozprawa druga}

\section{O różnicy między retorem a mówcą}

W tym miejscu, jak sądzimy, należy w jak najzwięźlejszy, a zarazem jak najbardziej wyczerpujący sposób przedstawić i wyjaśnić, jaka zachodzi różnica między retorem a mówcą. Oto bowiem retor odpowiednio słucha [jako ten], który albo uczy sztuki przemawiania i pokazuje sposoby ćwiczeń, albo też, gdy się go zapyta, wskazuje innym zasady wygłaszania i opracowywania mów, podczas gdy za mówcę uważa się kogoś, kto, jeśli jest biegły w słowach, podejmuje niebezpieczeństwo długiej przemowy i zgodnie z tym, czego wymaga sprawa, takie daje dowody swej biegłości, że im są one doskonalsze i wytworniejsze, tym więcej sławy i blasku zyskuje jego imię. Tak oto, żeby to, o czym mówiliśmy, zilustrować przykładem: retorem był Isokrates, mówcą Demostenes, Cycerona zaś słusznie obdarzymy jednym i drugim mianem. Poza tym to samo i to znacznie piękniej

przywołuje francuski jezuita Auzoniusza, Boecjusza, Kodeks Teodozjański i Sydoniusza Apollinarisa), ale też wczesnośredniowiecznych (Grzegorz z Tours) - zob. L. Cresollius, Theatrum veterum rhetorum, oratorum, declamatorum, quos in Grae-

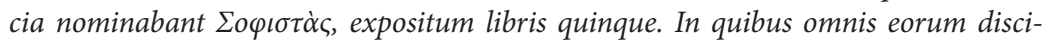
plina, et dicendi ac docendi ratio, moresque produntur, vitia damnantur, et magni utriusque linguae illustrantur et emaculantur scriptores, Paris: Sebastian Cramoisy, 1620 , s. 4-20.

${ }^{24}$ W starym druku błędnie: gentium. 
zostało wyłożone w nadzwyczaj przejrzysty sposób również przez wcale licznych autorów w tekście i w postaci wykazu, w którym te właśnie imiona zostały ułożone według kryterium wspomnianego rozróżnienia. Lecz my bynajmniej nie zamierzaliśmy wprowadzać tu tego samego w wersji opisowej. Jednakże zagadnień tych, gdy przedstawia się je na lekcjach, by adepci retoryki dobrze je zapamiętali, nie tylko nie odrzucamy, lecz wręcz do nich zachęcamy.

Skupionych na tym zadaniu bynajmniej nie chciałbym niepokoić, jeśli przypadkiem spostrzegą, że nie otrzymali żadnej listy skróconego już nazewnictwa, nawet jeśli doskonale zdają sobie sprawę z tego, że pisarze na wiele sobie pozwalają w rozmaicie sformułowanych słowach. Lecz jednak przyznajemy, że również sami mówcy, i to od samego początku, są naznaczeni mianem retorów, o którego trzech [znaczeniach] przypomina Caussin w księdze pierwszej $O$ wymowie świętej i ludzkiej, w rozdziale szóstym, więcej zaś na ten temat dowiadujemy się od Cresolliusa z Teatru retorów.

My z kolei, co zapowiadamy bardzo dobitnie, nie zamierzamy przedstawić tu retora, to jest nauczyciela retoryki, lecz jedynie wykształcić i ukształtować mówcę, odchodząc tym samym od zadań przypisanych retorowi, rodzącemu własnym wysiłkiem i staraniem mówcę. A ponieważ powicie bliźniąt nie jest porodem szczególnie niezwykłym, a jedynie hojnym, w tym samym wysiłku i trudzie poza mówcą wydamy na światło dzienne także uformowanego i sportretowanego retorystę, to jest ucznia retoryki. Niech wybrzmi to raz, nie trzeba powtarzać!

\section{[Dissertatio] quadragesima quarta}

\section{De auditore rhetorico seu rhetorista et nomenclaturae eius ventilatione}

Quod superest, auditorem nobis informatum ituris rhetoricum, hanc insidere sententiam: liquere potest apertissime, quod necesse esse arbitremur, ut ii, qui ad aliquam in eloquentia excellentiam adspirant, 
audiendi minime defugere debeant operam, sed ea, tanquam pene principe adminiculo, familiarissime uti potius.

Nempe duo haec maxima - inquit de garrulitate Plutarchus - prima et maxima audire et audiri ${ }^{25}$, quod cumprimis in rhetorices studio tam est verum, quam quod verissimum. [277] Id quod uti iam iam speciatim declaraturi sumus, ita idem in antecessum generatim hic a nobis perstringetur.

Quorsum quidem citra contoversiam spectat, quod ille de maiorum consuetudine ${ }^{26}$ commemoratum reliquit, qui, qualis eorum in educandis et praecolendis ad eloquentiam adolescentibus olim fuerit observatus modus, expositurus haec fecit verba: Apud maiores nostros iuvenis ille, qui foro et eloquentiae parabatur, imbutus iam domestica disciplina, refertus honestis studiis, deducebatur a patre vel a propinquis ad eum oratorem, qui principem locum in civitate tenebat. Hunc sectari, hunc prosequi, huius omnibus dictionibus interesse sive in iudiciis, sive in concionibus adsuescebat, ita ut altercationes quoque exciperet et iurgiis interesset, utque sic dixerim, pugnare in proelio disceret. Magnus vero ex hoc usus, multum constantiae, plurimum iudicii iuvenibus statim contingebat, in media luce studentibus, inter ipsa discrimina, ubi nemo impune stulte aliquid aut contrarie dicit, quo

25 Zob. Plutarch, De garrulitate, 2 (502 E). Mochinger albo daje tu własny przekład, albo nieznacznie modyfikuje tłumaczenie Wilhelma Xylandra; zob. Plutarchus Chaeroneus Ethicorum sive moralium pars II, Guilielmo Xylandro, Augustano, interprete [...], Frankfurt am Main: Johannes Saurius, 1603, s. 302: „duo autem haec et prima et maxima, audire et audiri”.

26 Tu przypis Mochingera: „ex Quintil(iano) Magiri in Polymn(emo) tit(ulo) de eloq(uentia) sect(ione) 20"; zob. T. Magirus, Polymnemon seu florilegium locorum communium. Ordine novo, exactiori et ad usum accommodatiori animatum selectioribus etiam sententiis et exemplis ex scriptorum probatissimorum et elegantissimorum, Graecorum, Latinorum, antiquorum, novorum, philosophorum, oratorum, poetarum, historicorum, legumlatorum, etc. monumentis consertum, sub quingentis quadraginta octo titulis [...], Frankfurt am Main: Clemens Schleich i wdowa po Danielu Aubriusie, 1629, kol. 913. W XVII wieku atrybucja Dialogus de oratoribus nie była jeszcze ustalona, stąd przypisanie tego dzieła przez Magirusa Kwintylianowi; obecnie dialog uznaje się za dzieło Tacyta. Poniżej cytat z Tacit., Dial. 34. 
minus et Iudex respuat, et adversarius exprobret, ipsi denique advocati adspernentur. Quod cum ita factum, quid aliud eopse indicatum ire voluerunt, [278] quam pro persuassissimo se id habere, nonnisi auscultatione aliorum fieri posse quenquam eloquentem?

Praeter quod etiam hoc a nobis statuitur, quod, etiamsi in aliis disciplinis absque auditu ad laudem fortean eniti possit quispiam, in oratoria tamen facultate nullo id ipsum fieri possit pacto, etsi (quod facile damus) solae auditiones omne negotium minime absolvant, cum et audientes imitari et aemulari, hoc est, dicendo vel referre, vel superare oporteat.

Quapropter immane quantum commovemur, cum hisce nostris videmus oculis, alia ad suadae regiam contendere via promiscuum adolescentium vulgus, qui dicere se etiam posse putant, imo et ad dicendum surgere nihil verentur, antequam dicentium aut docentium, quid $^{27}$ sit recte dicendum, auscultationes obiverint. Quod nisi est exorbitare, ecquid tandem aliud erit exorbitare? Unde tanta quidem, uti in propatulo est, auditorum in eloquentiae palaestra hodie est raritas, ut vix ullo in studiorum genere pauciores acroasibus deditos reperias, quam in eo, quod rhetoricae auditioni fideliter combibendae debetur.

Enimvero superioribus consimiliter annis [279] super eodem rectae in perorandi facultate comparanda rationis neglectu, dum paucos adeo, qui eloquentiae disciplinam profitentibus aures commodarent, observatum est exstare, querelam hanc eximius, si quisquam, nostrae artis professor, Siberus ${ }^{28}$ funditavit, hisce, quae in quadam ab ipso editorum dissertationum $\mathrm{p}$ (agina) 221. leguntur verbis: dicam

27 W starym druku błędnie: qui.

28 Adam Theodor Siber (łac. Siberus, 1563-1616), wykształcony na uniwersytetach w Lipsku, Jenie i Rostoku, od 1593 roku wykładał na uniwersytecie w Wittenberdze najpierw poetykę, a od 1597 język grecki i retorykę, autor m.in. potężnego (liczącego prawie tysiąc stron), wydanego w dwóch tomach w 1614 roku DIALEXE $\Omega N$ academicarum [...] volumen I, II (zob. G. Müller, Siber, Adam Theodor, w: Allgemeine Deutsche Biographie, Bd. 34, Leipzig 1892, s. 130). W Wittenberdze w latach 1620-1624 studiował również sam Mochinger (zob. B.B. Awia- 
ipse, quae vidi, quibus interfui. Anni sunt complures, cum in vicina Academia ${ }^{29}$ in literis viverem. Operam tum temporis dabam, sed cum paucissimis, doctori oratoriae, Iohanni Rivio ${ }^{30}$ : at cui viro? Omnium, quos ego in vita viderim, doctissimo atque eloquentissimo, qui tanquam Pericles alter, idque mirum quod sit et incredibile, in dictione potissimum, qua plurimum poterat, extemporali, sessitantem et ipse haberet Suadam illam ${ }^{31}$, orationis inauditae ac stupendae vim funditantem. Hunc tamen tantum oratorem (nam id nomen postea apud maximos Europae reges ac principes maxima cum gratia et gloria cumulatissime repraesentavit) plerumque octo, septem, sex audiebamus. Iam vero habuimus hic (puta Witebergae) paulo ante Michaelem Reichardum $^{32}$, hominem eruditissimum ac facundissimum, collegam amicumque mihi optatum ac desiderandum. Is quam frequenti docuerit auditorio, sensit ipse, [280] vidi ego, norunt alij33. Haec ille. Quibus gemina ex nostra addere possemus notitia, a quibus non in paucis

nowicz, Retoryka w Gdańskim Gimnazjum Akademickim..., s. 71 - tam też literatura na temat edukacji gdańskiego retora).

$29 \mathrm{Tj}$. uniwersytet w Lipsku.

30 Johannes Rivius (zm. po 1594), syn słynnego humanisty o tym samym imieniu (1500-1553), profesor uniwersytetu w Lipsku, w 1585 roku występował jako mówca w Polsce, w 1594 został inspektorem szkół w Rydze; autor Tabulae trium M.T. Ciceronis librorum de officiis (Basel 1561), Loci communes philosophici, qui ad logicam spectant, diagrammatum tabulis delineati (Glaucha 1579) i De lectione historiae (Wilno 1585).

31 Aluzja do Cic. Brut. 59, gdzie mowa o upersonifikowanej Swadzie - odpowiedniku greckiej Пعı $\theta \omega ́$, która według cytowanego przez Cycerona Eupolisa „miała siadywać na ustach Peryklesa” („Suadam [...], quam deam in Pericli labris scripsit Eupolis sessitavisse"). Dlatego też wbrew drukowi Mochingera, a zgodnie z edycją Siberusa, wprowadzono w tym miejscu pisownię Suadam wielką literą.

32 Chodzi tu o zmarłego w 1597 roku filozofa Michaela Reicharda (Starszego), ojca bardziej znanego pastora i matematyka o tym samym imieniu (Michael Reichard, 1592-1642).

33 Zob. A.T. Siberus, DIALEXESN academicarum, quae sunt orationes, praefationes, dissertationes, epistolae et carmina, vol. I, Wittenberg: Paul Helwich i Georg Müller, 1614, s. 221-222 (passus z wygłoszonej w 1597 r. „Dominica XXV post Trinitatis" mowy Ad studiosos eloquentiae in Academia Wittebergensi). Mochinger cytuje tekst Sibera wiernie, jedynie w charakterystyce Reicharda pomija unice przed 
itidem animadversum est Academiis, quomodo nonnisi numerabilis semper eorum, qui fida sedulitate rhetoricam tractavere, grex fuerit. Aut igitur longe retroactis seculis iuvenum cor rite magis saluit $^{34}$, aut tu valde fortunatus fuisti, Isocrates, qui primo quidem, cum apud Chios ludum eloquentia aperuisses, nonnisi novem habuisti auditores, sed paulo post Plutarcho ${ }^{35}$ in vita tua referente, etiam centum, cum domus tua, quasi quaedam officina, patuit, et ideo cum magni oratoris, tum perfecti magistri, quanquam luce carueris forensi, gloriam nomenque adeptus es. Neque vero rhetoricam docens, absque pretio tuae aperuisti artis mysteria, sed mille drachmarum, seu decem minarum praemium ${ }^{36}$ a discipulis exegisti. Proinde cum Demosthenes se tantum exsolvere non posse caussaretur, ac nonnisi ducentas, quo quintam artis partem disceret, se daturum pollicitus esset drachmas, respondisti: non concidimus commentationem nos-

mihi optatum, modyfikuje też nieznacznie interpunkcję. Ostatnie zdanie zdaje się aluzją do frazy Cic. Cat. 1, 2: „Senatus haec intellegit, consul videt, hic tamen vivit”. ${ }_{34}$ W starym druku błędnie: saliit. Wyrażenie zaczerpnięte od Plauta (Cist. 551: „cor salit”) lub Seneki Młodszego (Herc. O. 154: „cor attonitum salit”).

35 Mochinger daje tu przypis z lokalizacją cytatu: „in Vitis X Rhetor(um)”. Zob. Pseudo-Plutarch, Vita decem oratorum (Moralia, 837b-c).

36 Była to niebagatelna kwota, skoro attycka drachma ważyła $4,3 \mathrm{~g}$ srebra wysokiej próby, a medymnos zboża (ok. 52 l) w czasach akmé Isokratesa (pierwsza poł. IV w. p.n.e.) kosztował średnio 6 drachm (zob. S. von Reden, Money in Classical Antiquity, Cambridge 2010, s. 199-200). Wartości 10 min byli świadomi również profesorowie gdańskiego Gimnazjum Akademickiego - uczeń i następca Mochingera, Johann Peter Titz (1619-1689) w Commentatio tertia, nummaria z 1676 roku przeliczał minę attycką (100 drachm) na 12,5 ówczesnego talara (zob. J.P. Titius, Manuductio ad excerpendum. Insertae sunt observationes de vitiis Latini sermonis et locutione emendata eiusque auctoribus accesserunt Commentationes I. Didactica, de adminiculis linguae L(atinae), II. Prosodica, de stator. et cognatis, III. Nummaria, de pecunia vetere ac nova, abaco tabulisque exhibita. Cum indice plenissimo verborum, rerum, auctorum, Gdańsk: Christian Mannsklapp/David Fridericius Rhetius, 1676, s. 427). Informacja o honorarium w wysokości $1000 \mathrm{drachm}$ pochodzi z cytowanego wyżej Pseudo-Plutarcha (Moralia, 837d-e; por. też. Plutarch, Dem. 5, 848b, gdzie mowa o tej samej kwocie jako o 10 minach), który jednak dalej pisze (Moralia, 838f), że Isokrates nigdy nie brał honorariów od obywateli ateńskich. 
tram, frustillatimque, verum ut insignes totos pisces, vendimus ${ }^{37}$. Ita ego tibi, si lubebit, [281] a me accipere, integram artem tradam. Quid si vero hac tempestate tam multa sibi numerari quispiam vellet rhetorum, ecquanta tum demum futura esset in acroaterio eius solitudo? Cum nemo non hodie malit eloquentia carere, quam argento, et rei potius amplificandae invigilare, quam ampliandis orationibus.

Quicquid autem sit, auditorem esse attinet quemlibet, cui in dicendo progressus momenti alicuius facere est institutum. Quocirca nonnisi cum auditore rhetorico iam nunc negotium nobis esse futurum aperte edicimus, hoc est, cum eo, qui credere nobis non detrectat, audiendum sibi esse, ut discat, qui ad perorandum praeparare se debeat. Et hac in parte sui, quid sit muneris, fideliter, quoad eius a nobis fieri poterit, eum erudire accingimur.

Quod dum facimus, auditorem huncce rhetoricum, quod indictum relinquere non est visum, rhetoristam semel atque iterum nuncupabimus; Tauri videlicet, Gellium apud lib(rum) 17. cap(ite) 20. $N($ octium $)$ A(ticarum) celebratissimae memoriae philosophi ${ }^{38}$, exemplo, sic, uti dicto loco legitur, Gellium compellantis: Heus tu Rhetorista! [282] Videsne enthymema (in verbis Pausaniae a Platone in Symposio inductis) crebrum et coruscum et connexum, brevibusque et rotundis numeris, cum quadam aequabili circumactione devinctum? Habesne nobis dicere in libris rhetorum vestrorum tam apte tamque modulate compositam orationem? ${ }^{39}$ In quo quidem sermone quid

37 Anegdota według Vita decem oratorum (Plutarch, Moralia, 837b-c). Najprawdopodobniej Mochinger skorzystał tu z przekładu Hermanna Cruseriusa (zob. Plutarchus Chaeroneus, Ethica, sive Moralia, opera quae extant omnia, interprete Hermanno Cruserio [...], Basel: Thomas Guérin, 1573, s. 757).

38 Chodzi o greckiego filozofa należącego do tzw. Średniej Akademii, L. Calvenusa Taurusa (II w. n.e.), którego uczniem obok przywołanego tu rzymskiego erudyty Aulusa Gelliusza (druga poł. II w. n.e.) był słynny ateński mówca i polityk Herodes Attyk (101-ok. 177 n.e.).

39 Cytat za Gell. 17, 20, przy czym zarówno w wydaniach współczesnych, jak i dawnych terminy rhetorista i enthymema zapisane czcionką grecką (por. np. Aulus Gellius, Noctes Atticae. Accesserunt eruditissimi viri Petri Mosellani in easdem 
rhetoristae nomenclatura Taurus innuere voluerit, ipsemet ibidem loci Gellius, hac, quam ibi videre est, parenthesi inserta, cum inquit: Sic enim me in principio recens in diatribam acceptum appellitabat, existimans eloquentiae unius exercendae gratia Athenas venisse ${ }^{40}$, satis aperte declaratum ivit. Et post eum clarius Petrus Mosellanus ${ }^{41}$ hoc addito hypomnemate: Rhetorista, inquiens, est, qui rhetoribus operam navat. Graecis enim rhetor eloquens dicitur, unde fit rhetoristes, cuius vocativus est rhetorist $a^{42}$. Haec itaque nomenclationis istius, qua iterum iterumque utemur, nobis autoritas, cui parem an producere queant quidam alii, et cumprimis Iesuitae, qui suos in rhetorica ${ }^{43}$ auditores, uti e collegio Rhetorum Phorcensium Vernulaei ${ }^{44}$, quemad-

perdoctae adnotationes [...], Köln: Martinus Gymnicus, 1549, s. 640). Wtrącenie w nawiasie pochodzi od Mochingera.

40 Zob. Gell. 17, 20.

41 Petrus Mosellanus (1493-1524), niemiecki humanista, od 1517 roku profesor greki na uniwersytecie w Lipsku, a w latach 1520-1523 rektor tejże uczelni, autor wielu prac z zakresu retoryki, a także wydawca i komentator Gelliusza (jego Annotationes in Auli Gelli Noctes Attice ukazały się po raz pierwszy pośmiertnie w 1526 r. w Bazylei); więcej zob. B.B. Awianowicz, Petrus Mosellanus i jego De primis apud rhetorem exercitationibus praeceptiones, „Terminus” 5 (2003), z. 1, s. 224.

$42 \mathrm{~W}$ oryginalnych wydaniach Mosellanusa terminy zapisane $\mathrm{w}$ alfabecie gre-

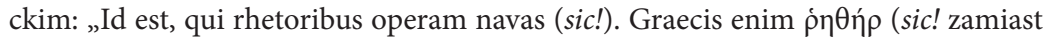

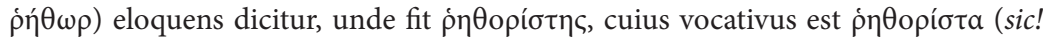
zamiast $\dot{\eta \tau o \rho i ́ \sigma \tau \eta ৎ ~ i ~ \rho ́ \eta \tau o \tau i ̃ \sigma \tau) " ~(z o b . ~ P . ~ M o s e l l a n u s, ~ A n n o t a t i o n e s ~ P e t r i ~ M o s e l l a-~}$ ni Protogensis in clarissimas Auli Gellii Noctes Atticas, Basel: Johann Bebel, 1526, [b.n.s.], oraz Aulus Gellius, Noctes Atticae..., s. 640).

${ }^{43} \mathrm{Tj}$. najwyższa klasa spośród stanowiących w kolegiach jezuickich, odpowiednik szkoły średniej humaniorów.

$44 \mathrm{Tj}$. Rhetorum collegii Porcensis orationes Nicolausa Vernulaeusa (de Vernulz, 1583-1649), łacińskiego dramaturga i profesora retoryki na uniwersytecie w Lowanium (Leuven), wydane po raz pierwszy w tamtejszej oficynie Flaviusa w 1614 roku, w kolejnych dekadach wielokrotnie wznawiane. Tytułowymi retorami są tu rzeczywiście studenci, jednak Vernulaeus, choć katolik, wbrew sugestii Mochingera, nie należał do Towarzystwa Jezusowego, zaś Collegium Porcense (dosł. „Świńskie Kolegium" - nider. Het Varken, fr. Collège du Porc) nie było kolegium jezuickim, a jednym z czterech najstarszych w Lowanium kolegiów uniwersyteckich, w których wykładano artes liberales. 
modum et Famiani Stradae prolusionibus ${ }^{45}$ paret patetque, rhetores vocitare solent, ipsi viderint. Rhetores ego dictos [283] apud priscos bonae notae autores reperi non discipulos, aut eloquentiae pullos, sed ipsos iam in orando perfectos, et in docenda iuventute aperiendisque dicendi fontibus occupatos. Teste vel uno, sed locuplete valde, nec non magna subscriptorum cincto copia, Cresollio, in Theatro rhetorum lib(ro) I cap(ite) $2^{46}$. At isodio hoc et quasi parasceve ${ }^{47}$ missa, ad rei caput nos convertamus ${ }^{48}$.

\section{Rozprawa czterdziesta czwarta}

\section{O słuchaczu retorycznym albo retoryście i o dyskusji na temat tej nazwy}

To, co nam jeszcze pozostaje, gdy chcemy ukształtować słuchacza retorycznego, to ugruntować tę oto opinię: może być czymś powszechnie wiadomym, co uznajemy za niezbędne, że ci, którzy dążą do jakiejś doskonałości w wymowie, w żadnym razie nie powinni stronić

45 Mowa tu o Prolusiones academicae włoskiego jezuity Famiana Strady (15721649), wydanych po raz pierwszy w Lyonie (u Horacego Cardona) w 1617 roku. Rzeczywiście Strada wielokrotnie zwraca się do adresatów swojego podręcznika jako do rhetores, ale niekiedy też jako do patres, co sugeruje, że swój wywód kierował zarówno do studentów ostatnich klas kolegiów, jak i ich profesorów (zob. np. F. Strada, Prolusiones academicae nunc demum ab auctore recognitae [...], Lyon: Horace Cardon, 1617, s. 1, 5, 18, 23, 26).

46 Zob. L. Cresollius, Theatrum veterum rhetorum..., s. 14-20. Francuski jezu-

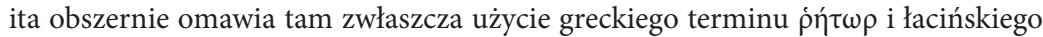
rhetor w Nowym Testamencie, u Diona z Prusy, Flawiusza Filostratosa, Grzegorza z Nazjanzu, Diodora Sycylijskiego, Tertulliana oraz u Cycerona i Kwintyliana.

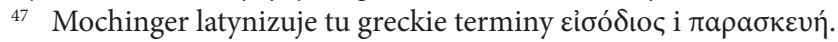

48 Autor zapowiada tu przejście od rozważań terminologicznych do rozdziałów poświęconych powinnościom i kompetencjom „retorysty” (s. 283-327). 
od słuchania, lecz raczej winni korzystać z niego jak najbardziej swobodnie, niczym z najbardziej podstawowej pomocy.

„Te dwie są zaiste najważniejsze - powiada Plutarch o gadulstwie - pierwsze i najważniejsze: słuchać i być słuchanym”, co zwłaszcza w zgłębianiu retoryki jest tak prawdziwe jak najprawdziwsza prawda. Jak już mieliśmy przedstawić to szczegółowo, tak najpierw dotkniemy tu tego jedynie ogólnie.

Niewątpliwie wiąże się z tym to, co o zwyczaju przodków przekazał ten, kto zamierzając wyłuszczyć, jaki obowiązywał u nich niegdyś wypróbowany sposób w kształceniu i we wprowadzeniu młodzieży do sztuki wymowy, pisał następująco: „U naszych przodków młody człowiek, który gotował się wystąpić jako mówca na forum, otrzymawszy już w domu początki wykształcenia i nakarmiwszy umysł szlachetnymi naukami, wiedziony był przez ojca lub jakiegoś krewnego do tego mówcy, który zajmował pierwsze stanowisko w państwie. Przyzwyczajał się uczęszczać do jego domu, towarzyszyć mu publicznie, przysłuchiwał się wszystkim jego przemówieniom, czy to w sądzie, czy na wiecach ludowych, do tego stopnia, że wchłaniał w siebie nawet obustronne repliki, obecny był przy gwałtownych sporach i - żeby się tak wyrazić - na polu bitwy uczył się walczyć. Wielkiego stąd doświadczenia, wiele pewności siebie, bardzo wiele krytycyzmu młodzieńcy od razu nabywali, studiując przy pełnym blasku dnia i wśród samych procesów, gdzie nikt bezkarnie nie może powiedzieć nic głupiego ani opacznego, żeby tego sędzia nie odparł, przeciwnik nie wytknął, żeby sami wreszcie adwokaci tego nie odrzucili”" ${ }^{49}$. Skoro tak było, cóż innego przez to chcieli obwieścić, jeśli nie to, że za rzecz absolutnie niewątpliwą uważali, jakoby tylko przez słuchanie innych mógł ktoś stać się dobrym mówcą?

Poza tym my również sądzimy, że nawet jeśli w innych dziedzinach bez słuchania zapewne można zdobyć jakąś sławę, w oratorstwie jednak w żadnym razie nie da się tego zrobić, jakkolwiek (co

49 Przekład (z niewielkimi zmianami) za: Tacyt, Dialog o mówcach, w: idem, Dzieła, t. 2, przeł. S. Hammer, Warszawa 1957, s. 358-359. 
łatwo przyznajemy) samo słuchanie nie jest bynajmniej czynnością wystarczającą, ponieważ słuchając, należy też naśladować i współzawodniczyć, to jest w mowie albo oddawać [styl słuchanego mówcy], albo [go] przewyższać.

Dlatego właśnie tak bardzo obrusza nas, gdy na własne oczy widzimy, że inną drogą zmierza do królewskiej siedziby swady pospolita ciżba młodzieńców, którzy, jak im się zdaje, potrafią mówić, a nawet w ogóle nie wahają się występować z mową, i to zanim przystąpią do wysłuchania mówców albo nauczycieli tego, jak należy właściwie przemawiać. Czymże to jest, jeśli nie pobłądzeniem, czy wreszcie coś innego będzie pobłądzeniem? Do tego dzisiaj nawet w sali ćwiczeń sztuki wymowy słuchacze są taką rzadkością, jak na zewnątrz, w przestrzeni publicznej, tak że z trudem znajdziesz w jakimkolwiek rodzaju studiów mniej ludzi oddanych wykładom niż w tym, który wymaga wiernego uczestnictwa w słuchaniu retora.

Tymczasem już bardzo podobnie w dawniejszych latach, kiedy jeszcze dawało się zauważyć choć kilku tych, którzy nadstawiają uszu na wykłady znawców teorii wymowy, ową skargę na ten sam temat zaniedbania właściwej metody przy kształtowaniu zdolności wygłaszania mów najlepiej rozwinął nie kto inny, jak profesor naszej dyscypliny Siberus w słowach, które czytamy na stronie 221 wydanych przez niego samego wykładów: „Powiem sam, co widziałem, przy czym byłem obecny. Już wiele lat minęło, odkąd w pobliskiej Akademii zajmowałem się studiami literackimi. Słuchałem wówczas gorliwie, lecz w bardzo niewielkim gronie, doktora sztuki oratorskiej Johannesa Riviusa. Cóż to za człowiek? Spośród wszystkich, których tylko w życiu widziałem, najuczeńszy i najbardziej wymowny, niczym drugi Perykles (co zadziwiające i wręcz niewiarygodne, zwłaszcza we współczesnej manierze przemawiania, którą znał on doskonale) miał ową przysiadającą Swadę, siłę wyrzucania z siebie mowy niesłychanej i obezwładniającej. Jednakże tego tak wielkiego mówcy (jego imię bowiem niezwykle hojnie obdarzali później wielką łaską i chwałą najwięksi w Europie królowie i książęta) słuchaliśmy przeważnie w ośmiu, siedmiu, sześciu. Mieliśmy już tu (mam na myśli Wittenbergę) niedawno Michaela Reicharda, człowieka 
znakomicie wykształconego i znakomitego mówcę, mego kolegę, jak też umiłowanego i drogiego mi przyjaciela. Przy jak dużym audytorium nauczał, on sam czuł, ja widziałem, inni wiedzieli”. Tyle tamten. Uwagi bliźniaczo podobne do powyższych moglibyśmy dodać także na podstawie tego, co również dało się zauważyć w wielu akademiach, jak zawsze nieliczne grono stanowili ci, którzy ze szczerą gorliwością poświęcali się retoryce; jeśli tylko da się ich policzyć, będzie to mrowie.

Albo więc w dawno minionych stuleciach serce młodzieży bardziej wyrywało się tam, gdzie należy, albo byłeś, Isokratesie, wielkim szczęściarzem, skoro najpierw, gdy otworzyłeś szkołę wymowy na Chios, miałeś raptem dziewięciu słuchaczy, lecz już wkrótce potem, jak podaje Plutarch w twoim żywocie, nawet stu, gdy twój dom, niczym jakiś warsztat, stał otworem, a do tego zyskałeś sobie sławę zarówno wielkiego mówcy, jak i doskonałego nauczyciela, chociaż brak ci było doświadczenia sądowego. I nauczając retoryki, bynajmniej nie odkrywałeś tajników twojej sztuki za darmo, lecz domagałeś się od uczniów honorarium w wysokości tysiąca drachm, czyli dziesięciu min [srebra]. Dlatego gdy okazało się, że Demostenes nie jest w stanie tyle zapłacić, a obiecał dać jedynie dwieście drachm, by nauczyć się jednej piątej sztuki, odpowiedziałeś: „Nie dzielimy naszego nauczania na kawałki, sprzedajemy tak, jak wielkie ryby, w całości”. Tak i ja tobie ofiarowuję całą naukę, o ile zechcesz ją ode mnie przyjąć. Gdyby zaś współcześnie któryś z retorów zechciał sobie tak wiele policzyć, jak wielka pustka doskwierałaby mu w sali wykładowej? Ponieważ dziś każdy woli obywać się raczej bez wymowy niż bez pieniędzy i dba raczej o powiększanie majątku niż doskonalenie mów.

Jakkolwiek by było, wypada mieć jakiegoś słuchacza, któremu wyznaczono robienie w wymowie jakichś postępów. Teraz już przeto otwarcie zapowiadamy, że nie zajmiemy się nikim innym, jak tylko słuchaczem retorycznym, to jest kimś takim, kto nie będzie się wzbraniał, by nam uwierzyć, że aby zdobyć wiedzę, sam musi słuchać, kto poświęci się przygotowaniom do przemawiania. I w tej części zabieramy się do kształcenia go tak wiernie, jak tylko będziemy w stanie, w tym, co jest jego powinnością. 
Póki to czynimy, owego słuchacza retorycznego, które to określenie lepiej porzucić, będziemy dalej nazywać retorystą. Jest to mianowicie określenie słynnego filozofa Taurusa, o którym czytamy u Gelliusza w dwudziestym rozdziale księgi siedemnastej Nocy attyckich, gdzie tak przemówił on do wspomnianego Gelliusza: „Hola, retorysto! Czyż nie widzisz entymematu (w słowach Pauzaniasza wprowadzonych w Uczcie Platona), liczny on i błyszczący, i powiązany krótkimi i okrągłymi liczbami, połączony z pewnym równomiernym obrotem. Czy potrafisz nam wskazać w księgach waszych retorów tak stosownie i tak harmonijnie ułożoną mowę?". W tej zaś rozmowie to, na co nazwą „retorysta” chciał wskazać Taurus, sam Gelliusz w tym samym miejscu dość dokładnie objaśnił, gdy mianowicie powiedział, stosując dającą się tu dostrzec taką oto parentezę: „Tak bowiem zwykł mnie nazywać, gdy dopiero co zostałem przyjęty do szkoły, sądząc, że przybyłem do Aten jedynie, by się ćwiczyć w wymowie". Po nim zaś jaśniej objaśnił to Petrus Mosellanus w tym oto dodanym komentarzu: „Retorystą jest ten, kto służy gorliwie retorom. Po grecku bowiem retorem zwie się mówcę, stąd pochodzi «rhetoristes», którego wołaczem jest "rhetorista»". Na takim oto autorytecie opiera się owa terminologia, z której częstokroć korzystamy. A jeśli inni potrafią opracować lepszą, zwłaszcza jezuici, którzy swoich słuchaczy w klasie retoryki, jak jasno wynika na przykład z Kolegium świńskich retorów Vernulaeusa oraz z Ćwiczeń Famiana Strady, zwykli nazywać retorami, niech sami tego próbują. $U$ dawnych, wysoko cenionych autorów znalazłem, że retorami zwani są nie uczniowie i młodzi adepci wymowy, lecz ci, którzy są już doskonałymi mówcami i zajmują się nauczaniem młodzieży i objaśnianiem źródeł wymowy. Niech za jedyne świadectwo, ale za to wielkiej wagi i oparte na bardzo wielu pisarzach, posłuży tu Cresollius w drugim rozdziale księgi pierwszej Teatru retorów. I porzucając to wprowadzenie i jakby przygotowanie, zwracamy się do głównego tematu. 


\section{Bibliografia}

\section{Źródła}

Caussin N., De eloquentia sacra et humana libri XVI. Editio tertia, non ignobili accessione locupleta, cum accuratis indicibus, tam eorum quae unoquoque capite continentur, quam rerum et verborum, Köln: Bernard Gualter, 1634 (Biblioteka PAN w Gdańsku, sygn. Fa $382548^{\circ}$ ).

Cresollius L., Theatrum verterum rhetorum, oratorum, declamatorum, quos in Grae-

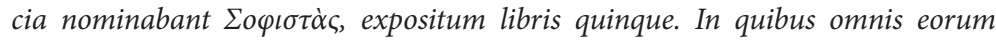
disciplina, et dicendi ac docendi ratio, moresque produntur, vitia damnantur, et magni utriusque linguae illustrantur et emaculantur Scriptores, Paris: Sebastian Cramoisy, 1620.

Cyceron M. Tulliusz, O mówcy, przeł., wstęp i komentarz B. Awianowicz, Kęty 2010.

Gellius Aulus, Noctes Atticae. Accesserunt eruditissimi viri Petri Mosellani in easdem perdoctae adnotationes [...], Köln: Martinus Gymnicus, 1549.

Magirus T., Polymnemon seu florilegium locorum communium. Ordine novo, exactiori et ad usum accommodatiori animatum selectioribus etiam sententiis et exemplis ex scriptorum probatissimorum et elegantissimorum, Graecorum, Latinorum, antiquorum, novorum, philosophorum, oratorum, poetarum, historicorum, legumlatorum, etc. monumentis consertum, sub quingentis quadraginta octo titulis [...], Frankfurt am Main: Clemens Schleich i wdowa po Danielu Aubriusie, 1629.

Mochinger J., Eloquentiae cupidissimos rhetoristas ad acroases oratorias frequenter iterum obeundas, quae (quod optimum maximum Numen iubeat!) auspicato rursus inchoabuntur, posteaquam quidem, solito in Acroaterio Minori Lycei nostri, die Martii I. hora sueta IXa, de librorum Tullianorum quam maxime utiliter evolvendorum ratione multo commodissima, quasi in antecessum, audita fuerint quaedam, allocutione publica vocoque invitoque, Johannes Mochingerus, Gymnasii rhetor, anno Domini MDC XLVI, Gdańsk: Rhetius, [1646] (Biblioteka PAN w Gdańsku, sygn. Ma $\left.39842^{\circ}(82)\right)$.

Mochinger J., Floridorum e disserationibus rhetoricis Johannis Mochingeri super Cicerone in Lyceo Gedanensi habitis excerptorum sylva, ed qua, in certos quasi saltus distributa, lectissimi aliquot eloquentiae alumni, facta sententiarum communicatione, nuncupandis suo loco diebus, sermones conferent, Gdańsk: Georg Rhete, 1640.

Mochinger J., Orator atque rhetorista penicillo Iohannis Mochingeri depicti prodiere, Gdańsk: Andreas Hünefeld, 1641.

Mosellanus P., Annotationes Petri Mosellani Protogensis in clarissimas Auli Gellii Noctes Atticas, Basel: Johann Bebel, 1526.

Plutarchus Chaeroneus, Ethica sive Moralia, opera quae extant omnia, interprete Hermanno Cruserio [...], Basel: Thomas Guérin, 1573. 
Plutarchus Chaeroneus, Ethicorum sive moralium pars II, Guilielmo Xylandro, Augustano, interprete [...], Frankfurt am Main: Johannes Saurius, 1603.

Siberus A.T., DIALEXESN academicarum, quae sunt orationes, praefationes, dissertationes, epistolae et carmina, vol. I, Wittenberg: Paul Helwich i Georg Müller, 1614.

Strada F., Prolusiones academicae nunc demum ab auctore recognitae [...], Lyon: Horace Cardon, 1617.

Tacyt, Dialog o mówcach, w: idem, Dzieła, t. 2, przeł. S. Hammer, Warszawa 1957. Titius J.P., Manuductio ad excerpendum. Insertae sunt observationes de vitiis Latini sermonis, et locutione emendata, ejusque auctoribus accesserunt Commentationes I. Didactica, de adminiculis linguae L(atinae), II. Prosodica, de stator. et cognatis, III. Nummaria, de pecunia vetere ac nova, abaco tabulisque exhibita. Cum indice plenissimo verborum, rerum, auctorum, Gdańsk: Christian Mannsklapp/David Fridericius Rhetius, 1676.

Vives J.L., Praelectio in quartum Rhetoricorum ad Herennium, w: idem, Early Writings 2. Epistula Forti, Vita Ioannis Dullardi, Christi Triumphus, Ovatio Mariae, Clipeus Christi, Praelectio in quartum Rhetoricorum ad Herennium, Praelectio in Convivia Philelphi, intr., critical ed., transl. and notes by J. IJsewijn, A. Fritsen, Ch. Fantazzi, Leiden 1991.

\section{Opracowania}

Awianowicz B.B., Petrus Mosellanus i jego De primis apud rhetorem exercitationibus praeceptiones, „Terminus” 5 (2003), z. 1, s. 223-241.

Awianowicz B.B., Progymnasmata $w$ teorii i praktyce szkoły humanistycznej od końca $X V$ wieku do połowy XVIII wieku. Dzieje nowożytnej recepcji Aftoniosa od Rudolfa Agricoli do Johanna Christopha Gottscheda, Toruń 2008.

Awianowicz B.B., Retoryka w Gdańskim Gimnazjum Akademickim w świetle programów szkolnych, wykładów i praktyki oratorskiej drugiej połowy XVI i XVII wieku, w: W gdańskim ogrodzie Muz. Gimnazjum Akademickie w Gdańsku wobec kultury starożytnych Greków i Rzymian, red. M. Otto, J. Pokrzywnicki, Pelplin 2015, s. 41-66.

Mokrzecki L., Jan Mochinger, w: Słownik biograficzny Pomorza Nadwiślańskiego, t. 3, red. Z. Nowak, Gdańsk 1997, s. 240-241.

Müller G., Siber, Adam Theodor, w: Allgemeine Deutsche Biographie, Bd. 34, Leipzig 1892, s. 130.

Nadolski B., Jan Mochinger - profesor retoryki w Gdańskim Gimnazjum Akademickim, „Rocznik Gdański” 22 (1963), s. 193-221. 
Nadolski B., Ze studiów nad życiem literackim i kulturą umysłową na Pomorzu w XVI i XVII wieku, Wrocław 1969.

Ramminger J., Neulateinische Wortliste, hasło rhetorista; www.neulatein.de/words/ 1/006541.htm (dostęp: 16.05.2018).

Reden S. von, Money in Classical Antiquity, Cambridge 2010. 